Available online at: https://proceeding.researchsynergypress.com/index.php/rsfconferenceseries1

RSF Conference Series: Business, Management and Social Sciences

e-ISSN 2807-5803/ p-ISSN 2807-6699

Volume 1 Number 3 (2021): 147-156

\title{
SWOT and Strategy for The Development of Salt Industry in Sumbawa Regency
}

\author{
Ninik Probosari ${ }^{1}$, Kartika Ayu Ardhanariswari², Ari Wijayani ${ }^{3}$ \\ ${ }^{1}$ Faculty of Economics and Business, Universitas Pembangunan Nasional "Veteran" Yogyakarta \\ ${ }^{2}$ Faculty of Social and Political Sciences, Universitas Pembangunan Nasional Veteran Yogyakarta \\ ${ }^{3}$ Faculty of Agriculture, Universitas Pembangunan Nasional Veteran Yogyakarta
}

\begin{abstract}
This study aims to find out how the strategy is in an effort to improve and develop people's salt management in Sumbawa Regency. The problem faced is the problem of competitiveness and product added value which is still low, so that it leads to the level of the economic welfare of the economic actors in the salt sector. To overcome these problems, a Salt Development Strategy is needed in order to have competitiveness. SWOT analysis (Strengths, Weaknesses, Opportunities, Threats) is used in research to develop strategies by considering strengths and weaknesses (internal environment) as well as opportunities and threats (external environment) faced by the Regional Government of Sumbawa Regency in order to develop its salt potential. The method of data collection was carried out by the method of Focused Group Discussion, Participatory Resource Mapping, observation, interviews, and literature study. The research subjects are stakeholders in Sumbawa Regency, namely the Sumbawa Regency Government, Academics, Entrepreneurs/Industry, and Salt Farmers Community. This research is a type of qualitative descriptive research. The resulted of this research were the strategies to develop the salt industry. Those strategies were: 1). Increasing the salt business system financing program, 2). Facilitating group or institutional development through collaboration with related parties, 3). Education about salt innovation and technology, 4). Increased cooperation with the government, especially the Cooperatives, Trade, and UMKM Service and the Fisheries and Marine Service, 5). Strengthening institutional management through various human resources education and training, 6). Strengthening capital capabilities and business partnerships, 7). Improvement of supporting facilities and infrastructure, 8). Development of salt business through the introduction of side businesses supporting the salt industry and 9). Establishment of a salt business association in the context of sharing information and experiences related to the world of salt.
\end{abstract}

Keywords: Development Strategy, SWOT Analysis, Salt Industry

This is an open access article under the CC-BY-NC license

\section{INTRODUCTION}

One of the important and strategic national commodities is salt. Salt is a product of the basic chemical industry group Chlor Alkali which consists of consumption salt and industrial salt. In the industrial sector, salt is used for various purposes such as the textile, oil, ceramics, pharmaceutical and paper industries, metal processing industry, soap industry, rubber industry. Salt as a food ingredient is a complementary material and a source of nutrition that cannot be replaced by other products, while the industrial sector uses salt as a raw material in the manufacture of various industrial products, including the production of PVC pipes, soap, cosmetics, textile manufacture, and other industrial products. Until now, Indonesia still imports about 2 million tons of salt/year. 
Realizing the importance of salt commodity, the government prioritizes the National Industrial Development Master Plan 2015-2035. In practice, the industrial sector requires salt of higher quality than the quality of salt for household consumption. It is this high-quality salt that must be met by domestic salt producers, even though, in fact, the fulfillment of salt for household needs can already be fulfilled. Salt demand from the industrial sector alone contributes $40 \%$ of the total national salt demand, so a breakthrough is needed from the Government and salt producers to meet the demand for quality salt. Fulfillment of national salt needs should indeed receive special attention from the government because, until today, the fulfillment of national salt needs has not been able to be carried out independently. The resources owned by Indonesia are actually sufficient to be self-sufficient in salt. In the context of meeting national salt needs, Indonesia is a country that has the second-longest coastline in the world, so it is possible to be able to meet its national salt needs, and it is not impossible to become one of the largest salt exporters in the world. At least there are 48 regencies/cities listed as salt industry centers. All of these areas are on the coast and the sea (Yonvitner and Surya, 2018). One of these regencies is Sumbawa Regency, Nusa Tenggara Barat (NTB). NTB is one of the national salt buffer provinces. According to Yusron, as Head of the NTB Marine and Fisheries Service, Sumbawa is one of the regencies in NTB that has a potential salt-producing area. Sumbawa has a potential salt-producing land area of 3,502 hectares (Ha). However, in this area, the use of salt land is only $5 \%$ of the potential land area or only about $175.35 \mathrm{Ha}$ (DKP Sumbawa Regency, 2020).

The problem faced by the salt industry in the Sumbawa district is the problem of competitiveness and product added value which is still low, so that it leads to the level of the economic welfare of the economic community in the salt sector. Specifically, the problem lies in the weakness of salt farmers' institutions, the weakness of the people's salt trading system (price, quality, and distribution of salt), inadequate production facilities and infrastructure, limited capital and business management as well as weak regulations and the absence of a salt supervisory agency in Sumbawa Regency. Until now, the Sumbawa Regency does not yet have a roadmap and strategic plan (renstra) for this salt, while salt is one of the superior products of the Sumbawa Regency. The Roadmap and Strategic Plan are very important in order to be a direction for the development of competitive people's salt. So, the problem of this research is how the strategy to develop increasing the salt industry in Sumbawa Regency.

To overcome these problems, it is necessary to map the development of people's salt. This mapping will take the form of a people's salt development strategy plan. It is hoped that this strategic plan will help Sumbawa Regency in increasing the competitiveness of salt as one of the leading products. This strategic plan will be prepared based on a SWOT (Strengths, Weakness, Opportunity, Threats) analysis.

In order to encourage the realization of salt self-sufficiency as well as to increase productivity, quality, and added value of salt for salt farmers in Sumbawa Regency, the aspect of structuring management from upstream to downstream is of special attention and is part of the main instrument in the regional development planning framework of Sumbawa Regency. Especially at this time, the Regional Government is encouraging the optimization of the potential utilization of natural resources, including salt, so that it can be used as a center for the salt industry. This is because the position of the Sumbawa Regency has been used as a buffer location for meeting the national salt needs.

In order to make salt one of the superior products towards the national salt buffer area, it is necessary to have proper management of this people's salt. Therefore, the Sumbawa Regency Government needs to implement an effective strategy by utilizing its internal strengths, namely opportunities and strengths, by considering external influences in the form of threats and weaknesses to develop Sumbawa people's salt products or known as SWOT analysis (Strength, Weakness, Opportunity, Threats). This 
research using the SWOT technique was once carried out by Syafruddin (2020). Another research conducted by Danu Kusbandono (2019), the results of this study is the selection of strategies resulting from the SWOT analysis has an effect on the selection of new business locations and company development activities. In line with this research is research from Rahmayati HM (2015), which concludes that with a SWOT analysis, various alternatives for business development can be obtained.

Fredy Rangkuti (2008:18) explains that to systematically identify various factors in the organization, it is necessary to formulate a strategy that can be used with SWOT analysis (Strengths, Weaknesses, Opportunities, Threats). This analysis is based on the logic that can maximize strengths and opportunities but simultaneously minimize weaknesses and threats. It is hoped that this roadmap and strategic plan will serve as the basis for analysis and decision-making for economic growth.

An activity similar to the SWOT analysis was carried out by Ninik Probosari (2019) in her involvement in the preparation of the Magelang District Education Office Masterplan. The Master Plan serves as a guide for realizing the development of a region. Inherent in this function is the use of the Master Plan as a reference for monitoring and evaluating the stages of development that have been taken. In addition, Ninik Probosari (2015) has also been involved in the preparation of the FEB UPN Veteran Yogyakarta Strategic Plan, which discusses a lot about this SWOT analysis.

The objective of this research is to analyze the salt development strategy in order to optimize salt management so that it has competitiveness in Sumbawa Regency.

\section{LITERATURE REVIEW}

\section{Definition of SWOT Analysis}

According to Rangkuti (2013: 198), SWOT analysis is a systematic identification of various factors to formulate a company strategy. This analysis is based on the logic that can maximize strengths (Strengths) and opportunities (Opportunities) but simultaneously can minimize weaknesses (Weaknesses) and threats (Threats). Susanto (2014:131) explains the ability of SWOT analysis to survive as a planning tool that is still being used today. SWOT analysis has become the framework of choice for many managers because of its simplicity, presentation process, and ability to reflect the essence of strategy development, namely linking opportunities and threats with strengths and weaknesses. SWOT analysis is used by a company or organization to find out the strengths of the organization that are not owned by other organizations, as well as to find out the weaknesses that exist in the organization itself. In addition, opportunities and threats can be identified for the organization. Strengths, weaknesses, opportunities, and threats in an organization will be able to determine an effective strategy with the expected results.

This technique, which operates by 'peeling back layers of the company is designed for use in the preliminary stages of decision-making processes and can be used as a tool for evaluation of the strategic position of organizations of many kinds (for-profit enterprises, local and national governments, NGOs, etc.) (Caves, 2004). It is intended to specify the objectives of the business venture or project and identify the internal and external factors that are favorable and unfavorable to achieving those objectives. Users of a SWOT analysis often ask and answer questions to generate meaningful information for each category to make the tool useful and identify their competitive advantage. SWOT has been described as the tried-andtrue tool of strategic analysis but has also been criticized for its limitations (Dess, 2018).

The SWOT analysis has been used in community work as a tool to identify positive and negative factors within organizations, communities, and the broader society that promote or inhibit the successful implementation of social services and social change efforts. It is used as a preliminary resource, assessing 
strengths, weaknesses, opportunities, and threats in a community served by a nonprofit or community organization (Westhues et al., 2001)

\section{Environmental Observation}

Before starting strategy formulation, managers must observe the external environment to identify opportunities and threats that may occur. According to Hunger et al. (2003:113), to observe the environment, strategic managers must first know the various conditions that exist in the social environment and work environment. The social environment includes general forces that are not directly related to short-term organizational activities but can influence long-term decisions, namely:

a. The economic forces that govern the exchange of materials, money, energy, and information.

b. The power of technology that results in problem-solving inventions.

c. The power of political law that allocates power and provides for the coercion and protection of laws and regulations.

d. Sociocultural forces that govern the values, customs, and habits of the environment.

The work environment includes elements or groups that have a direct effect on the company. The company's work environment is generally the industry in which the company operates. These environmental factors are divided into two, namely:

\section{Internal Environment}

According to Jatmiko (2004:68), Internal environmental analysis is also called analysis of company strengths and weaknesses, analysis of organizational capabilities and culture, or sometimes also called analysis of organizational/company identity, is an analysis of company resources and industry opportunities. The identification of factors contained in the company's internal environment is as follows:

\section{Marketing Aspect}

Marketing is the process of determining, anticipating, creating, and satisfying customer needs for products or services.

\section{Financial and Accounting Aspects}

Financial condition is often considered as the best measure of the strength or competitive position of the company and the main attraction for investors. Determining the financial strengths and weaknesses of the organization/company is important in formulating an effective strategy.

\section{Aspects of Human Resources}

Human resources are internal environmental factors in the company that carries out all activities within the company. Companies can work well if they have human resources who have the capability, expertise in competition, and good management.

\section{Aspects of Production/Operations and Researcher Development}

Production activities represent the largest part of the human resources and capital of an organization. Research and development specifically also affect the strengths and weaknesses of the company. 


\section{Information System Aspect}

The information system is a term related to the formal mechanism by which every organization should use information systems to obtain information about the relevant external environment and about the internal capabilities of the organization itself.

\section{External Environment}

The external environment can be said as components that are or come from outside the organization/company. These components tend to be outside the reach of the organization, meaning that the organization/company cannot intervene on these components. Components are more likely to be needed as something that is given or something that inevitably must be accepted (Dirgantoro, 2004: 40).

\section{RESEARCH METHOD}

The analytical method used in this research uses mixed analysis, called qualitative descriptive analysis techniques. Descriptive analysis is an analysis of a process situation and certain symptoms or objects being observed (Ruslan, 2008). The qualitative analysis consists of three flows of activities that occur simultaneously between data reduction, data presentation, and conclusion drawing. The subjects in this research are the parties who are closely related to the development of this people's salt. In specific, this research adopted a case study which, according to Cavus and Juma'h (2001), is a research strategy that focuses on understanding the dynamics present within single settings. Case studies can involve either single or multiple cases and numerous levels of analysis. One of the aims of using this sort of research method is to give a description (Pinfield, 1986). This research adopted an in-depth interview, literature study, focus group discussion, and participatory data gathering techniques. Data gathered focused on answering how the Sumbawa Regency had developed the salt industry. The respondents in this research are 15 people as represented by four stakeholders in the development of people's salt in the Sumbawa regency.

The first step for the case study was identifying the research question and select the case. Focusing research questions and case helps to specify the necessary data and data gathering techniques relevant to the research. The second step of this research was collecting data from stakeholders of salt industry development. They include academics, business, government, and community. The third step was data analysis. The focus of this step was to identify the potentials factors of Sumbawa Regency to be triggers and the roles of stakeholders in developing the salt industry. The fourth step was formulating and interpreting the findings of data analysis. The researchers formulate and interpret during data collection. So that in the final stages of research, researchers can obtain the final results of the continuation of the interpretation process for the information obtained while conducting research. The final step was the presentation of the final result about SWOT Analysis and the development strategies of the salt industry in Sumbawa Regency.

\section{FINDINGS AND DISCUSSION}

In this section, the results of research that have been carried out on the object of research will be displayed. Data analysis using the SWOT method. SO Strategy (Strength Opportunity Strategy) is a strategy made by utilizing all strengths to obtain and take advantage of opportunities that exist in the external environment of Sumbawa salt industrialization. The WO (Weakness Opportunity Strategy) strategy is a strategy that is applied to improve the weaknesses of the internal environment of Sumbawa salt industrialization by taking advantage of existing opportunities from the external environment. ST Strategy 
(Strategy Threats Strategy) is a strategy that uses the strengths possessed to avoid or overcome threats that come from the external environment. WT Strategy (Weakness Threats Strategy) is a strategy based on activities and tries to minimize existing weaknesses and avoid threats.

Table 1. SWOT Matrix

\begin{tabular}{|c|l|l|}
\hline EFAS & $\begin{array}{l}\text { Strengths } \\
\text { (S) }\end{array}$ & $\begin{array}{l}\text { Weaknesses } \\
(\mathrm{W})\end{array}$ \\
\hline $\begin{array}{l}\text { Opportunities } \\
(\mathrm{O})\end{array}$ & Strategy SO & Strategy WO \\
\hline Threats (T) & Strategy ST & Strategy WT \\
\hline
\end{tabular}

Source: Rangkuti, 2008

\section{Identification of Strengths, Weaknesses, Opportunities, and Threats in the Context of Developing People's Salt.}

The SWOT analysis is prepared by considering the Internal Strategic Factors Analysis Summary (IFAS) and External Strategic Factors Analysis Summary (EFAS).

Internal Strategic Factors Analysis Summary (IFAS).

IFAS is structured to formulate internal strategic factors (Strengths and Weaknesses)

Strengths:

a. The community already has a culture of salt farmers.

b. The National Gudang Garam (GGN) has been built, which will become the Gudang Garam Receipt System in Labuhan Bontong Village, Tarano District.Have a representative land.

c. Political stability and security are quite good.

d. The existence of financial institutions that are ready to distribute credit funds.

Weaknesses:

a. The low level of capital capacity results in low investment by farmers in cultivation and salting technology.

b. Farmers' absorption of salting technology innovation is relatively low.

c. The pattern of developing salt farmers has not been carried out intensively and systematically.

d. Salt farmers are still a subsystem. The existence of the salt farmers' cooperative is still not optimal in bringing prosperity to its members.

e. The salt business association has not yet been formed in Sumbawa Regency.

External Strategic Factors Analysis Summary (IFAS)

EFAS is structured to formulate external strategic factors (Opportunities and Threats)

Opportunities:

a. The existing land has the potential to improve the quality and competitiveness of Sumbawa salt.

b. There is determination and willingness of the government and local governments to carry out the industrialization of salt. 
c. Most salt farmers need farming capital.

d. Available credit funds from financial institutions/banks.

e. The digital market platform opens wide market access for industrial salt and consumption salt commodities.

Threats:

a. There is no local government policy that provides certainty of standard prices for raw material salt, and there are no incentives for salt industry players.

b. The invasion of imported salt with good quality and competitive prices threatens the national salt industry.

c. The expansion of salt ponds on a large scale destroys mangrove conservation areas along the coast.

d. The government's lack of supervision over the imported salt trade system causes the people's salt absorption capacity to be low and prices uncompetitive.

\section{Development Strategy of Sumbawa People's Salt.}

\section{SO (Strength-Opportunity) Strategy}

The SO strategy is a strategy created by using strengths from the internal environment to take advantage of opportunities from the external environment in the development of the Sumbawa people's Gram. The strategies are as follows:

a. Optimize the salt business system financing program by increasing the amount of salt business capital loans. Financing for farmers can take advantage of credit from banks.

b. The government can facilitate the development of groups or institutions through cooperation with related parties.

\section{ST Strategy (Strength - Threats)}

This strategy based on strengths and threats is a strategy created by using strengths sourced from the internal environment to overcome threats from the external environment in developing a salt production environment. The strategies are as follows:

a. Provide education about salt innovation and technology.

b. Increase cooperation with the government, especially the Cooperatives, Trade, and UMKM Service and the Fisheries and Marine Service

\section{WO Strategy (Weakness - Opportunities)}

This strategy based on weaknesses and opportunities is a strategic idea created by minimizing weaknesses originating from the internal environment to take opportunities from the external environment in the salt development strategy. The strategies are as follows:

a. Improving the professionalism of institutional management through various human resources education and training.

b. Increase cooperation with related parties in reducing the risk of default due to crop failure, for example, with insurance institutions that can facilitate insurance, especially for farmers.

c. Improvement of supporting facilities and infrastructure, especially other supporting equipment that is not yet available, so as to facilitate the process of production and distribution of salt. 


\section{WT Strategy (Weakness - Threats)}

This strategy that comes from weaknesses and threats is a strategy that is created by minimizing weaknesses that come from the internal environment and is also used to avoid threats from the external environment. The strategies are as follows:

a. Strengthening cooperation with related parties, especially the government, to provide stimulants to salt farmers.

b. Develop the salt business through the introduction of a side business supporting the salt industry.

c. Establish a salt business association at the district level in order to share information and experiences related to the world of salt.

Based on the analysis of internal and external factors in the salt sector in Sumbawa, it can be seen that there are still opportunities for the salt sector to develop to be more advanced and productive. In order for this to be implemented, the local government needs to first strengthen its internal capacity, especially improving management, including strengthening the quality of its human resources (HR). Good management will certainly bring its own advantages for the growth of the salt sector because it will facilitate the planning, implementation, and evaluation of each activity of the salt community. In addition, good management will give a good image to external parties, both the salt farming community, so that the community and other institutions will be easy to collaborate with. The government from the village to the central level also needs to continue to provide support, both in the form of capital participation and coaching for salt farmers.

This research was applied research, so there was no novelty/new theory from this research. This study seeks to apply a SWOT analysis to obtain a strategy for the development of the salt industry in the Sumbawa Regency.

\section{CONCLUSION AND FURTHER RESEARCH}

Based on the results of the analysis, it can be concluded that the strategies that can be carried out in the community are as follows:

1. Optimize the salt business system financing program by increasing the amount of salt business capital loans. Financing for farmers can take advantage of credit from banks.

2. The government can facilitate the development of groups or institutions through cooperation with related parties.

3. Provide education about salt innovation and technology.

4. Increase cooperation with the government, especially the Cooperatives, Trade, and MSMEs and the Fisheries and Marine Service

5. Improving the professionalism of institutional management through various human resources education and training.

6. Increase cooperation with related parties in reducing the risk of default due to crop failure, for example, with insurance institutions that can facilitate insurance, especially for farmers.

7. Improvement of supporting facilities and infrastructure, especially other supporting equipment that is not yet available, so as to facilitate the process of salt production and distribution.

8. Strengthening cooperation with related parties, especially the government, to provide stimulants to salt farmers.

9. Develop the salt business through the introduction of a side business supporting the salt industry. 
10. Establish a salt business association at the district level in order to share information and experiences related to the world of salt.

This study has a weakness in the SWOT analysis as it is known that this SWOT analysis has a point of view that is too subjective. In-depth data and studies can actually be applied in making a SWOT analysis, but sometimes it causes a SWOT analysis to be not simple. The basis for determining internal and external factors should not be predictive results. Likewise, the resulting strategy cannot be obtained only from intuition. For further research, the Analytical Hierarchy Process (AHP) can be used, which is a management tool for tiered and complex decision-making processes. AHP can objectify the results of IFAS and EFAS.

\section{ACKNOWLEDGMENT}

The authors would like to thank the Institute for Research and Community Service at Universitas Pembangunan Nasional Veteran Yogyakarta, Indonesia, for providing funds for this research.

\section{REFERENCES}

Caves, R. W. (2004). Encyclopedia of the City. Routledge. p. 653. ISBN 978-0415862875.

Cavus, M., \& Juma'h, A. H. (2001). Describing case study method and identifying the factors that contribute to the successful conduct of case studies https://dire.upr.edu/handle/11721/1333

Danu Kusbandono. (2019). SWOT Analysis as a Business Strategy Development and Strengthening Effort. JPIM, Volume 4 Nomer 2 Juni 2019, p-ISSN: 2502-3780, e-ISSN: 2621-881X.

Dess, Gregory. (2018). Strategic Management. United States: McGraw-Hill. p. 73. ISBN 9781259927621.

Hunger, David K and Thomas L. Wheeln. (2003). Strategic Management. Yogyakarta: Andi Offset.

Ihsanudin \& Subejo, (2016). Salt Farmers Economic Empowerment Strategy Through Utilization of Salt Land Assets, Economics Development Analysis Journal 5 (4).

Jatmiko, RD. (2004). First Edition: Strategic Management. Malang: UMM Press.

$\begin{array}{lllll}\text { Kasmui. (2011). Preparation of roadmap (roadmap). Via } & \end{array}$ http://repo.unnes.ac.id/document/roadmap-unnes.

Makhfud Effendy et al. (2012). People's Salt: Potential and Problems. UTM Press, Trunojoyo University, Madura.

Moleong, Lexy J. (2007). Qualitative Research Methodology. Bandung: PT Pemuda Rosdakarya Offset.

n.d. (2020). Potential Area, Level of Land Use and Salt Production of Sumbawa Regency in 2018. Marine and Fisheries Service of Sumbawa Regency. Not Published.Ninik Probosari (2015). FEB UPNVY Strategic Plan. Not Published.

Ninik Probosari. (2019). Master Plan of the Education Office of Magelang Regency. PT Sinergi Utama Vision. Not published.

Pinfield, L. T. (1986). A Field Evaluation of Perspectives on Organizational Decision Making. Administrative Science Quarterly, 31(3), 365-388. JSTOR. https://doi.org/10.2307/2392828.

Rahmayanti. (2015). SWOT In determining the frozen shrimp marketing strategy. Jurnal Galung Tropika., Number 4 (1). Januari. 2015. ISSN on line 2407-6279. ISSN Cetak: 2302-4178.

Rangkuti, Freddy. (2013). SWOT analysis: The technique of dissecting business cases. Jakarta: Gramedia. 
Siagian, Sondang. (2012). Human Resource Management. Jakarta: Earth Literacy.

Susanto, AB. (2014). Comprehensive Strategic Management. Jakarta : Erlangga.

Syafrudin. (2020). SWOT and Development Strategy for BUMDes in Usar Village. IPPeMas National Seminar Proceedings.

Westhues, Anne; Jean Lafrance; Glen Schmidt (2001). "A SWOT analysis of social work education in Canada". Social Work Education: The International Journal. 20 (1): 35-56. doi:10.1080/02615470020028364.

Yonvitner \& Surya (2018). Building a Competitive Salt Governance. Minutes of Agricultural and Environmental Policy Vol. 5 No.1, April, 27-33 ISSN : 2355-6226. E-ISSN : 2477-0299 